\title{
Peer Influence dan Konsumsi Makanan Cepat Saji Remaja di SMAN 6 Surabaya
}

\section{Peer Influence and Fast Food Consumption among Adolescent at SMAN 6 Surabaya}

\author{
Khairina Fadiah Hidayati*1, Trias Mahmudiono ${ }^{1}$, Annas Buanasita², Fransiska Sabatini Setiawati ${ }^{1}$, Nadia Ramadhani ${ }^{1}$
}

\begin{abstract}
ABSTRAK
Latar Belakang: Remaja memiliki ciri-ciri ingin diterima oleh kelompok sebayanya (peer). Peer influence juga bisa memengaruhi konsumsi, salah satunya konsumsi makanan cepat saji, mancanegara maupun domestik. Peer influence yang tinggi memiliki kemungkinan untuk membuat konsumsi makanan cepat saji remaja menjadi tinggi.

Tujuan: Penelitian ini dilakukan untuk menganalisis hubungan antara peer influence dan konsumsi makanan cepat saji, mancanegara maupun domestik.

Metode: Penelitian ini merupakan penelitian observasional analitik dengan studi cross sectional pada 136 remaja di SMAN 6 Surabaya yang dipilih secara clustered random sampling. Data yang dikumpulkan adalah latar belakang responden berupa, jenis kelamin, usia, serta uang saku harian. Selain itu, responden diminta mengisi peer influence scale questionnaire dan food frequency questionnaire mengenai makanan cepat saji.

Hasil: Sebagian besar responden memiliki peer influence rendah (52,21\%). Uji korelasi chi square mengungkapkan adanya hubungan yang signifikan antara peer influence dan konsumsi french fries $(p=0,016)$, beef burger $(p=0,029)$, chicken burger $(p=0,025)$, dan waffle $(p=0,014)$. Tidak ada makanan dari kelompok makanan cepat saji domestik yang memiliki hubungan yang signifikan dengan peer influence.

Kesimpulan: Terdapat hubungan antara konsumsi beberapa jenis makanan cepat saji mancanegara dan peer influence. Jenis makanan cepat saji yang memiliki korelasi dengan peer influence yaitu french fries, beef burger, chicken burger, dan waffle. Sedangkan tidak ada makanan dari kelompok makanan cepat saji domestik yang memiliki hubungan yang signifikan dengan peer influence. Hal ini mengungkapkan bahwa peer influence hanya memengaruhi makanan cepat saji tertentu yang memiliki nilai prestige.
\end{abstract}

Kata Kunci: peer influence, food prestige, remaja, makanan cepat saji mancanegara, makanan cepat saji domestik

\section{ABSTRACT}

Background: Adolescent have the characteristics of wanting to be accepted by their peers. Peer influence can also affect consumption, one of which is consumption of fast food, either foreign or domestic. High peer influence has the possibility to make fast food consumption high.

Objectives: This research was conducted to analyze the correlation between peer influence and consumption of fast food, foreign and domestic.

Methods: This study was an observational analytic study with a cross sectional design on 136 adolescents in SMAN 6 Surabaya who were selected by clustered random sampling. Data collected were the respondent's background: gender, age, and daily pocket money. Respondents also filled a peer influence scale questionnaire and a food frequency questionnaire about fast food.

Results: Most respondents had low peer influence (52.21\%). The chi square correlation test revealed that there was a significant correlation between peer influence and consumption of French fries $(p=0.016)$, beef burger $(p=0.029)$, chicken burger $(p=0.025)$, and waffle $(p=0.014)$. There was no significant correlation between peer influence and any food from domestic fast food group.

Conclusions: There was a correlation between several types of foreign fast food consumption and peer influence. Types of fast food that had a correlation with peer influence were French fries, beef burger, chicken burger, and waffle. Whereas no 
food from domestic fast food groups had a significant correlation with peer influence. This revealed that peer influence only affects certain fast food that has prestige value.

Keywords: peer influence, food prestige, adolescent, foreign fast food, domestic fast food

\author{
*Koresponden: \\ hidayatikhairina@outlook.com \\ Khairina Fadiah Hidayati \\ ${ }^{1}$ Departemen Gizi Kesehatan \\ Fakultas Kesehatan Masyarakat - Universitas Airlangga, Indonesia \\ ${ }^{2}$ Akademi Gizi Surabaya Indonesia
}

\section{PENDAHULUAN}

Generasi berusia muda, khususnya remaja, merupakan generasi penerus bangsa. Generasi ini perlu untuk disiapkan, fisik maupun mentalnya, agar generasi ini memiliki kualitas yang baik. Persiapan fisik, di antaranya, adalah persiapan kesehatan. Meski masih berusia belia, generasi ini bukannya bebas dari masalah kesehatan, termasuk masalah gizi.

Salah satu masalah gizi yang mungkin dihadapi oleh generasi ini adalah masalah obesitas. Di Indonesia, kejadian gemuk pada remaja berusia 15-18 tahun terus meningkat dari tahun ke tahun, sejak tahun $2010^{1}$ $(1,4 \%), 2013^{2}(7,3 \%)$, hingga $2018^{3}(9,5 \%)$. Hal ini dapat menjadi masalah kesehatan, utamanya saat remaja tersebut beranjak dewasa.

Obesitas pada masa remaja dapat menyebabkan penyakit kronis pada daur hidup selanjutnya. Penelitian case contro/ $^{4}$ menunjukkan bahwa remaja obesitas cenderung memiliki tunika intima karotis yang lebih tebal, profil lipid yang lebih tinggi, dan tekanan darah yang lebih tinggi daripada remaja dengan status gizi normal. Penelitian lainnya ${ }^{5}$ menunjukkan bahwa terdapat hubungan antara kejadian hipertensi dan status gizi obesitas pada remaja. Hal ini menunjukkan bahwa remaja yang mengalami obesitas menunjukkan gejala awal dari penyakit-penyakit kronis.

Salah satu yg menyebabkan obesitas adalah konsumsi makanan cepat saji. Makanan cepat saji adalah makanan yang proses pengolahan dan proses konsumsinya memiliki durasi yang cepat ${ }^{6}$. Terdapat 2 jenis makanan cepat saji, yakni makanan cepat saji mancanegara dari restoran yang biasanya berasal dari luar negeri, dan makanan cepat saji domestik yang dijual di warung sunda, rumah makan padang, dan lainnya? Makanan cepat saji yang disajikan dan dikonsumsi secara cepat memiliki masalah kandungan gizi. Makanan cepat saji cenderung tinggi kalori namun tidak memiliki zat gizi yang bervariasi, terutama serat dan mikronutrien. Tingginya kalori pada makanan cepat saji ini dapat memicu terjadinya obesitas.

Penelitian dengan responden pelajar SMA/SMK di Kota Gorontalo8 memiliki kesimpulan bahwa konsumsi fast food merupakan salah satu faktor risiko obesitas. Penelitian lainnya berupa kasus dan kontrol pada remaja SMA di Kota Pontianak ${ }^{9}$ menunjukkan bahwa konsumsi fast food memiliki hubungan yang bermakna dengan kejadian obesitas. Penelitian di Yogyakarta ${ }^{10}$ dengan responden yang lebih muda, yaitu remaja di usia SMP, juga menunjukkan adanya hubungan antara konsumsi makanan cepat saji dengan kejadian obesitas. Sehingga, dapat disimpulkan bahwa salah satu faktor risiko obesitas adalah konsumsi makanan cepat saji.

Remaja sendiri merupakan kelompok usia yang unik. Salah satu keunikannya adalah tingginya peer influence. Pengambilan keputusan kelompok usia remaja banyak dipengaruhi oleh hal ini ${ }^{11}$. Selain orangtua, peer influence juga merupakan faktor yang memengaruhi perilaku minum minuman keras pada remaja di Korea ${ }^{12}$. Bahkan, tak hanya perilaku, pengetahuan mengenai kesehatan juga memiliki hubungan dengan peer influence ${ }^{13}$. Peer influence juga dapat memengaruhi citra tubuh pada remaja putri ${ }^{14}$. Peer influence dapat pula memengaruhi keputusan remaja dalam hal diet dan konsumsi makanan, khususnya makanan cepat saji. Penelitian pada pelajar remaja di Amerika ${ }^{15}$ menunjukkan bahwa peer influence meningkatkan frekuensi kunjungan ke restoran yang menjual makanan cepat saji. Selain itu, penelitian dengan responden remaja mahasiswa ${ }^{16}$ menunjukkan bahwa peer influence merupakan hal yang memengaruhi pemilihan makanan responden, sedangkan iklan tidak memiliki hubungan dengan pemilihan makanan sama sekali.

Berdasarkan paparan di atas, penelitian terkait hubungan antara peer influence dan konsumsi makanan cepat saji dipandang perlu. Tujuan dari penelitian ini adalah mengetahui hubungan antara peer influence dan konsumsi jenis makanan cepat saji, khususnya di SMAN 6 Surabaya, pada tahun 2019. SMAN 6 Surabaya dipilih karena berada di pusat Kota Surabaya, sehingga akses pelajar menuju makanan cepat saji cenderung lebih mudah. Prevalensi gemuk di SMAN 6 Surabaya juga telah mencapai $14 \%{ }^{17}$, lebih tinggi daripada kejadian gemuk nasional saat ini $^{3}$. Selain itu, berdasarkan observasi lapangan, di kantin SMAN 6 Surabaya tersedia banyak makanan cepat saji. Penelitian terkait hal ini juga belum pernah dilakukan di SMAN 6 Surabaya.

\section{METODE}

Metode yang digunakan pada penelitian ini adalah observasional analitik dengan menggunakan studi cross sectional. Penelitian dilakukan pada bulan April 2019 di Sekolah Menengah Atas Negeri 6 Surabaya. Populasi pada penelitian ini berjumlah 614 orang yang merupakan pelajar Sekolah Menengah Atas Negeri 6 Surabaya yang duduk di kelas $X$ dan $X I$. 
Gambar 1. Kerangka Operasional Penelitian

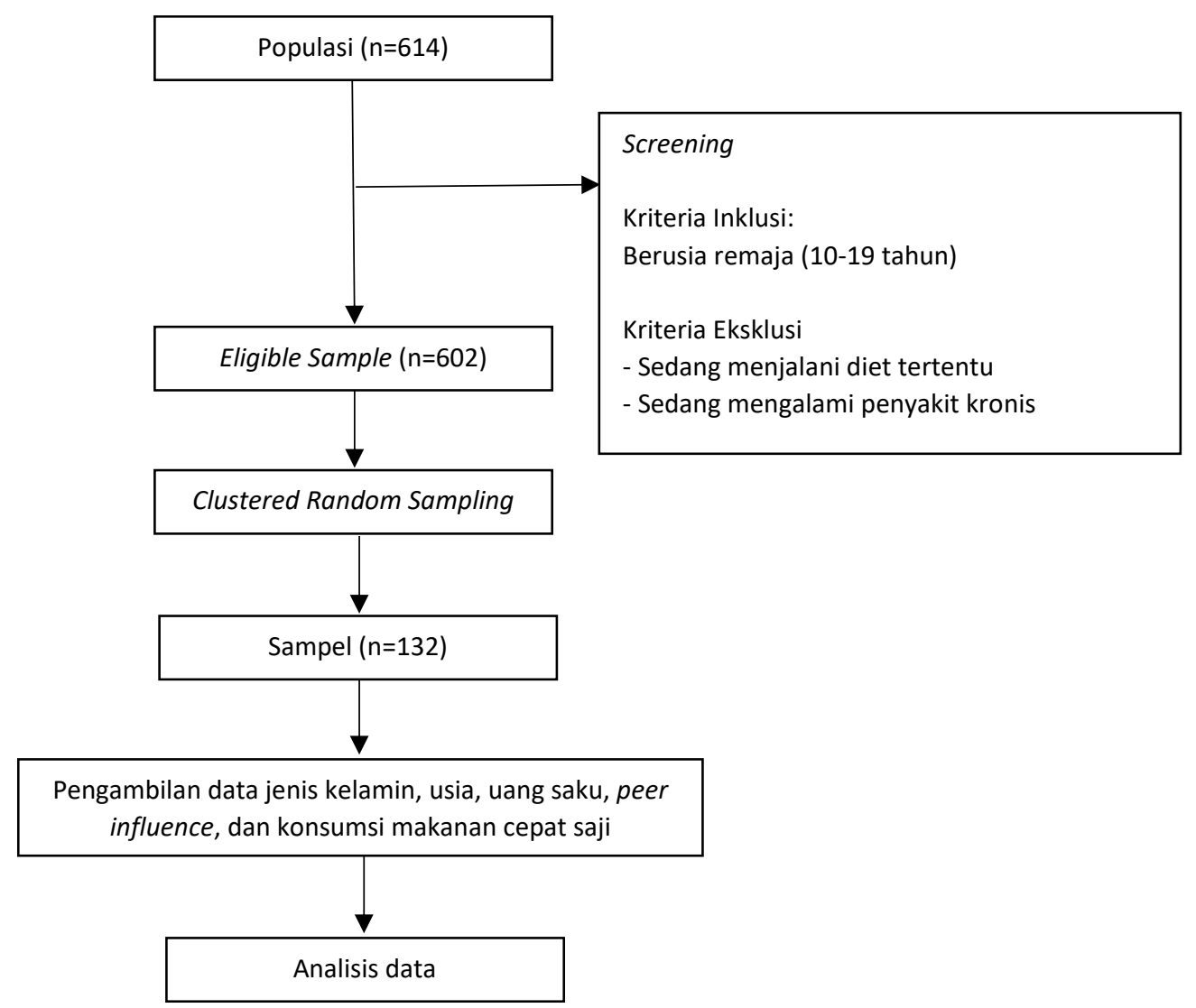

Besar sampel yang dibutuhkan dihitung dengan menggunakan rumus Lemeshow ${ }^{18}$, dan didapatkan sampel minimal sejumlah 82 orang. Pengambilan sampel pada penelitian ini menggunakan clustered random sampling sehingga jumlah sampel minimal dikalikan dengan design effect ${ }^{19}$ sebesar 1,6 dan menjadi 132 orang. Cluster yang digunakan dalam penelitian ini adalah kelas (rombongan belajar). Berlaku kriteria inklusi dan eksklusi pada penelitian ini. Kriteria inklusinya adalah berada dalam rentang usia remaja (1019 tahun ${ }^{20}$ ), sedangkan kriteria eksklusinya adalah sedang menjalani diet tertentu dan sedang mengalami penyakit kronis. Kerangka operasional penelitian ini dapat dilihat pada gambar 1.

Pengumpulan data terdiri dari latar belakang responden (jenis kelamin, usia, uang saku harian), peer influence, dan frekuensi konsumsi makanan cepat saji. Orangtua dari calon responden akan diminta tanda tangannya di lembar informed consent, setelah responden maupun orangtua responden mendapat penjelasan sebelum persetujuan. Apabila orangtua responden memberikan consent, dilakukan pengisian kuisioner data diri, terdiri dari jenis kelamin, tanggal lahir, usia, serta uang saku harian. Kuisioner selanjutnya adalah peer influence scale ${ }^{21}$, terdiri dari 23 pertanyaan mengenai peer influence secara umum dan 7 pertanyaan mengenai peer influence yang berkaitan dengan makanan cepat saji. Pertanyaan memiliki pilihan jawaban berupa skala Likert, dengan skor 1 untuk Sangat Tidak Setuju dan 5 untuk Sangat Setuju. Skor dikategorikan berdasarkan rata-rata, apabila skor responden di bawah rata-rata, maka peer influence masuk ke dalam kategori rendah. Sebaliknya, apabila skor peer influence responden ada di atas rata-rata, maka responden masuk ke dalam kategori pengarih tinggi.

Setelah itu, dilakukan pengukuran konsumsi makanan cepat saji dengan menggunakan food frequency questionnaire mengenai makanan cepat saji. Makanan dicantumkan pada food frequency questionnaire didasarkan pada wawancara dan focus group discussion dengan peserta 12 orang dari populasi penelitian, serta melalui observasi lapangan di SMAN 6 Surabaya dan daerah sekitarnya. Food frequency questionnaire juga dibatasi hanya untuk makanan cepat saji, yaitu makanan yang proses pengolahan dan proses konsumsinya memiliki durasi yang cepat ${ }^{6}$. Food frequency questionnaire terbagi menjadi 2 bagian, yakni bagian makanan cepat saji mancanegara dan makanan cepat saji domestik, masing-masing berjumlah 14 dan 21 makanan. Jawaban dari food frequency questionnaire dibagi menjadi konsumsi harian, mingguan, dan bulanan untuk tiap menu makanan. Setelah itu, untuk menganalisis odds ratio, dilakukan penyesuaian data food frequency questionnaire makanan cepat saji menjadi status konsumsi makanan cepat saji dalam 1 bulan terakhir (ya/tidak).

Setelah dilakukan pengisian kuisioner oleh responden, data dimasukkan ke dalam perangkat lunak IBM Statistical Package for Social Sciences (SPSS) versi 24. Data latar belakang responden dan diolah secara 
deskriptif, sedangkan data peer influence dan konsumsi makanan cepat saji dianalisis secara inferensial menggunakan uji korelasi chi square.

Penelitian ini telah mendapat izin dari Badan Kesatuan Bangsa dan Politik Provinsi Jawa Timur nomor 070/3066/209.4/2019 serta dari Dinas Pendidikan Provinsi Jawa Timur nomor 420/101.6.25/2019. Penelitian juga telah dinyatakan laik etik oleh Komisi Etika Penelitian Kesehatan FKM Unair nomor 165/EA/KEPK/2019.

\section{HASIL DAN PEMBAHASAN}

Penelitian ini dilakukan di SMAN 6 Surabaya yang berlokasi di Jalan Gubernur Soeryo No. 11, Kota Surabaya. Wilayah ini termasuk dalam pusat Kota Surabaya. Lokasinya yang stategis memudahkan pelajar di SMAN 6 Surabaya mengakses makanan cepat saji. Berdasarkan observasi, makanan cepat saji juga banyak tersedia di kantin SMAN 6 Surabaya.

Latar belakang responden pada penelitian ini adalah jenis kelamin, usia, dan jumlah uang saku. Berdasarkan tabel 1 , sebagian besar responden $(61,7 \%)$ memiliki jenis kelamin perempuan. Usia responden berada di antara 15-18 tahun, dan rata-rata usia responden adalah 16 tahun. Rata-rata uang saku responden adalah Rp17.507. Sebagian besar responden memiliki uang saku dibawah rata-rata $(52,21 \%)$, serta sebagian responden $(52,21 \%)$ memiliki peer infuence rendah.

Tabel 1. Distribusi Jenis Kelamin, Usia, dan Uang Saku Responden

\begin{tabular}{|c|c|c|c|c|}
\hline $\begin{array}{c}\text { LATAR } \\
\text { BELAKANG }\end{array}$ & & $\mathrm{n}$ & $\%$ & mean \\
\hline \multirow{2}{*}{$\begin{array}{c}\text { JENIS } \\
\text { KELAMIN }\end{array}$} & Laki-laki & 52 & 38,24 & \\
\hline & & 84 & 61,76 & \\
\hline \multirow{4}{*}{$\begin{array}{c}\text { USIA } \\
\text { (TAHUN) }\end{array}$} & 15 & 15 & 11,03 & \multirow{4}{*}{16} \\
\hline & 16 & 77 & 56,62 & \\
\hline & 17 & 40 & 29,41 & \\
\hline & 18 & 4 & 2,94 & \\
\hline \multirow{2}{*}{$\begin{array}{c}\text { UANG SAKU } \\
\text { (RUPIAH) }\end{array}$} & $<$ mean & 71 & 52,21 & \multirow{2}{*}{17.507} \\
\hline & $>$ mean & 65 & 47,79 & \\
\hline \multirow{2}{*}{$\begin{array}{c}\text { PEER } \\
\text { INFLUENCE } \\
\text { (KATEGORI) }\end{array}$} & Rendah & 71 & 52,21 & \multirow[b]{2}{*}{-} \\
\hline & Tinggi & 65 & 47,79 & \\
\hline
\end{tabular}

Tabulasi silang antara peer influence dan konsumsi masing-masing makanan cepat saji menunjukkan bahwa responden paling banyak mengonsumsi chicken burger dengan periode bulanan, (60 orang) serta peer influence rendah. Tidak ada responden yang mengonsumsi chicken burger dengan periode harian. Untuk menu beef burger, sebagian besar responden (54 orang) mengonsumsi secara bulanan dengan peer influence rendah. 3 orang responden mengonsumsi beef burger secara harian dengan peer influence tinggi. Untuk menu waffle, sebagian besar (50 orang) responden mengonsumsi dengan periode bulanan dengan peer influence rendah. Terdapat 5 responden yang mengonsumsi waffle dengan periode harian dengan kategori peer influence tinggi. Sebagian besar (48 orang) responden mengonsumsi french fries secara bulanan dengan kategori peer influence rendah. Tidak ada responden yang mengonsumsi french fries secara harian.

Hasil uji korelasi menggunakan uji chi-square yang dapat dilihat pada tabel 2 menunjukkan bahwa hanya beberapa makanan cepat saji dari kelompok makanan cepat saji mancanegara yang memiliki korelasi dengan peer influence. Makanan tersebut adalah french fries $(p=0,016)$, beef burger $(p=0,029)$, chicken burger $(p=0,025)$, dan waffle $(p=0,014)$. Makanan cepat saji domestik yang tidak memiliki hubungan dengan peer influence di antaranya bakso $(p=0,935)$, nasi goreng $(p=0,545)$, mie instan lokal $(p=0,737)$, pentol $(p=0,2)$, dan lain-lain. Hal ini sejalan dengan penelitian pada mahasiswa 22 yang menunjukkan bahwa peer influence hanya memengaruhi kelompok makanan cepat saji mancanegara. Penelitian yang dilakukan di Depok, Jawa Barat ${ }^{7}$ juga memiliki kesimpulan yang sama.

Untuk mengetahui lebih lanjut mengenai hubungan peer influence dan konsumsi makanan cepat saji mancanegara, dilakukan perhitungan odds ratio antara peer influence dan konsumsi makanan cepat saji mancanegara. Setelah menyesuaikan data konsumsi makanan cepat saji menjadi status konsumsi makanan cepat saji dalam satu bulan terakhir, didapatkan nilai OR pada tabel 3. Dapat disimpulkan bahwa responden yang memiliki peer influence besar, memiliki risiko 1,855 kali lebih besar untuk mengonsumsi french fries, 2,624 kali lebih besar untuk mengonsumsi beef burger, 1,881 kali lebih besar untuk mengonsumsi chicken burger, dan 1,052 kali lebih besar untuk mengonsumsi waffle.

Penelitian ini mengungkap bahwa peer influence memiliki hubungan dengan konsumsi makanan cepat saji mancanegara tertentu. Makanan cepat saji mancanegara kebanyakan dijual di cabang restoran dari luar Indonesia. Selain itu, harganya lebih mahal. Hal ini dapat memunculkan food prestige untuk makanan tersebut. Nilai prestige dari makanan dapat menimbulkan peer influence untuk mengonsumsi makanan cepat saji jenis tersebut ${ }^{23}$. Konsumsi makanan tidak hanya memiliki konsekuensi secara biologis, tapi juga secara sosial. Penelitian di 3 Kota Besar di pulau Jawa, yaitu Surabaya, Yogyakarta, dan Bandung ${ }^{24}$ juga mengungkapkan bahwa salah satu faktor yang memengaruhi pembelian makanan cepat saji mancanegara adalah faktor lingkungan sosial. Lokasi SMAN 6 Surabaya yang masuk dalam wilayah perkotaan dapat memengaruhi hal ini. Penelitian yang dilakukan di wilayah perkotaan Brazil ${ }^{25}$ membuktikan hal ini. Pada wilayah perkotaan, makanan tertentu seperti lasagna, barbecue, dan cake memiliki nilai prestige lebih daripada makanan lainnya makanan cepat saji domestik. Bahkan, penelitian di Yogyakarta dengan responden mahasiswa ${ }^{26}$ mengungkapkan bahwa motivasi responden untuk mengonsumsi minuman susu bukanlah motivasi 
kesehatan, namun karena nilai prestige yang melekat

pada minuman tersebut.

Tabel 2. Tabulasi Silang dan p-value Peer Influence dan Konsumsi Makanan Cepat Saji Responden

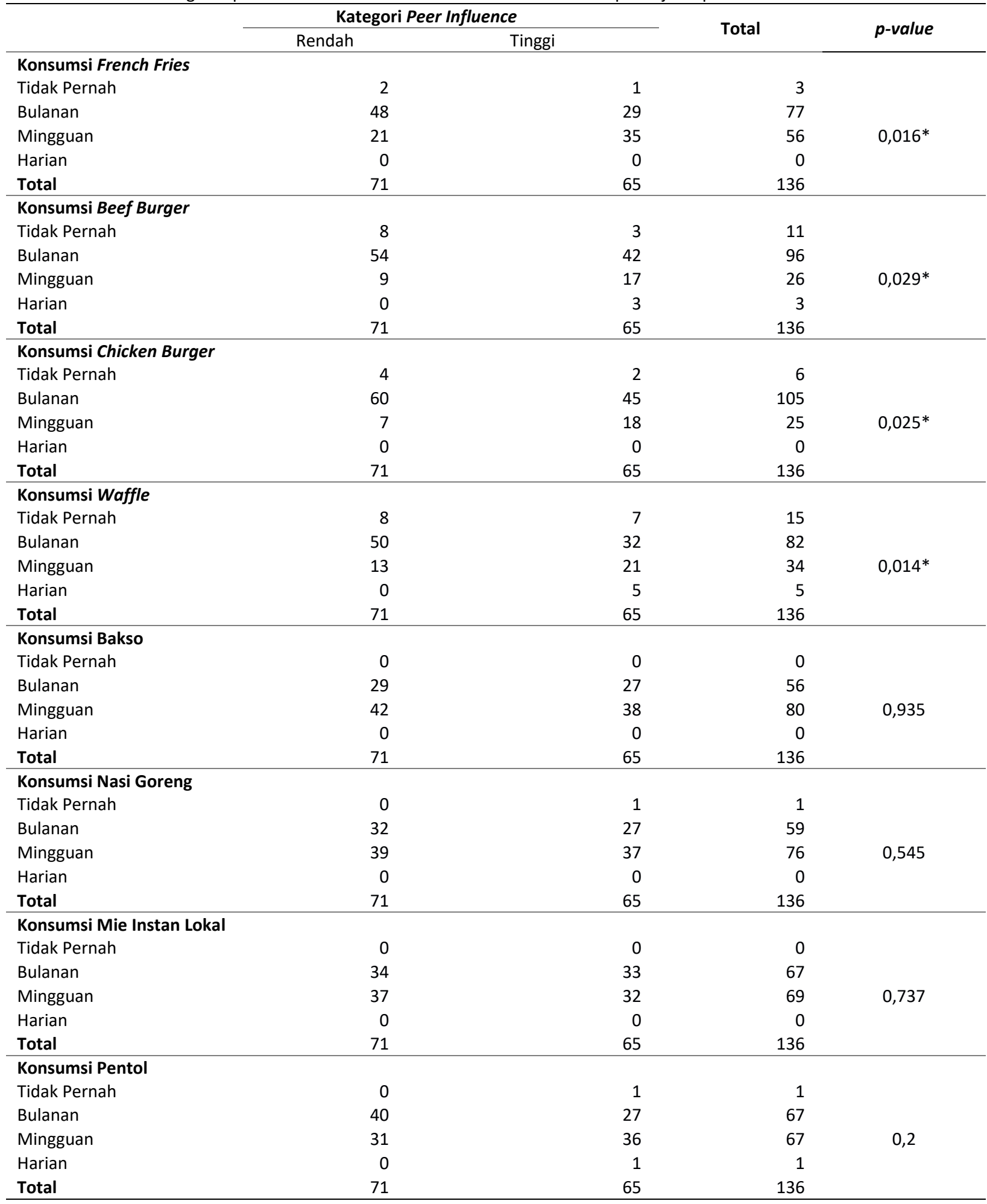

*memiliki hubungan signifikan

Food prestige juga dipengaruhi oleh globalisasi yang terjadi. Penelitian di India ${ }^{27}$ mengungkapkan bahwa wilayah tempat makanan cepat saji mancanegara dijual, utamanya makanan cepat saji mancanegara yang dijual melalui restoran dari luar India, memiliki nilai prestige tertentu. SMAN 6 Surabaya sebagai lokasi dari penelitian ini juga terletak di pusat kota Surabaya, dimana cabang dari restoran makanan cepat saji mancanegara dari luar negeri juga banyak dijual. 
Tabel 3. Tabulasi Silang dan Odds Ratio Peer Influence dan Status Konsumsi Makanan Cepat Saji Responden

\begin{tabular}{|c|c|c|c|c|c|c|c|}
\hline \multirow{3}{*}{$\begin{array}{l}\text { Konsumsi Menu Dalam } \\
\text { Sebulan Terakhir }\end{array}$} & \multicolumn{4}{|c|}{ Kategori Peer Influence } & \multirow{2}{*}{\multicolumn{2}{|c|}{ Total }} & \multirow{3}{*}{$\begin{array}{c}\text { OR } \\
(95 \% \mathrm{Cl})\end{array}$} \\
\hline & \multicolumn{2}{|c|}{ Rendah } & \multicolumn{2}{|c|}{ Tinggi } & & & \\
\hline & $\mathrm{n}$ & $\%$ & $\mathrm{n}$ & $\%$ & $\mathrm{n}$ & $\%$ & \\
\hline \multicolumn{7}{|l|}{ French Fries } & \multirow{3}{*}{$\begin{array}{c}1,855 \\
(0,072-14,291)\end{array}$} \\
\hline Ya & 69 & 50,7 & 64 & 47,1 & 133 & 97,8 & \\
\hline Tidak & 2 & 1,5 & 1 & 0,7 & 3 & 2,2 & \\
\hline \multicolumn{7}{|l|}{ Beef Burger } & \multirow{3}{*}{$\begin{array}{c}2,624 \\
(0,554-11,188)\end{array}$} \\
\hline Ya & 63 & 46,3 & 62 & 45,6 & 125 & 91,9 & \\
\hline Tidak & 8 & 5,9 & 3 & 2,2 & 11 & 8,1 & \\
\hline \multicolumn{7}{|l|}{ Chicken Burger } & \multirow{3}{*}{$\begin{array}{c}1,881 \\
(0,204-8,632)\end{array}$} \\
\hline Ya & 67 & 49,3 & 63 & 46,3 & 130 & 95,6 & \\
\hline Tidak & 4 & 2,9 & 2 & 1,5 & 6 & 4,4 & \\
\hline \multicolumn{7}{|l|}{ Waffle } & \multirow{3}{*}{$\begin{array}{c}1,052 \\
(0,298-2,794)\end{array}$} \\
\hline Ya & 63 & 46,3 & 58 & 42,6 & 121 & 89 & \\
\hline Tidak & 8 & 5,9 & 7 & 5,1 & 15 & 11 & \\
\hline \multirow{10}{*}{\multicolumn{4}{|c|}{$\begin{array}{l}\text { Penelitian selanjutnya dapat meneliti } \\
\text { mengenai food prestige yang ada pada fast food } \\
\text { mancanegara dan korelasinya dengan peer influence. } \\
\text { Kelebihan dari penelitian ini adalah, penelitian mengenai } \\
\text { hubungan peer influence dan konsumsi makanan cepat } \\
\text { saji belum pernah dilakukan di SMAN } 6 \text { Surabaya } \\
\text { sebelumnya. Keterbatasan yang ada pada penelitian ini } \\
\text { adalah, variabel peer influence diukur menggunakan peer } \\
\text { influence scale, belum melalui observasi langsung } \\
\text { ataupun metode wawancara kualitatif yang akan } \\
\text { mengungkap peer influence secara lebih mendalamm }{ }^{28,29} \text {. }\end{array}$}} & & \multirow{10}{*}{\multicolumn{3}{|c|}{$\begin{array}{l}\text { rendah }(52,21 \%) \text {. Uji korelasi chi square mengungkapkan } \\
\text { adanya hubungan antara beberapa jenis makanan cepat } \\
\text { saji mancanegara dan peer influence. Jenis makanan } \\
\text { cepat saji yang memiliki korelasi dengan peer influence } \\
\text { yaitu french fries }(p=0,016) \text {, beef burger ( } p=0,029) \\
\text { chicken burger ( } p=0,025) \text {, dan waffle }(p=0,014) \text {. Namun } \\
\text { tidak ada makanan dari kelompok makanan cepat saj } \\
\text { domestik yang memiliki hubungan yang signifikan } \\
\text { dengan peer influence. Hal ini mengungkapkan bahwa } \\
\text { peer influence hanya memengaruhi makanan cepat saj } \\
\text { tertentu yang memiliki nilai prestige. }\end{array}$}} \\
\hline & & & & & & & \\
\hline & & & & & & & \\
\hline & & & & & & & \\
\hline & & & & & & & \\
\hline & & & & & & & \\
\hline & & & & & & & \\
\hline & & & & & & & \\
\hline & & & & & & & \\
\hline & & & & & & & \\
\hline
\end{tabular}

\section{KESIMPULAN}

Penelitian pada 136 pelajar SMAN 6 Surabaya dengan latar belakang responden sebagian besar perempuan $(61,76 \%)$, rata-rata berusia 16 tahun, sebagian besar memiliki uang saku dibawah rata-rata $(52,21 \%)$, dan sebagain besar memiliki peer influence

\section{REFERENSI}

1. Riset Kesehatan Dasar 2010. (2010). Available at:

http://kesga.kemkes.go.id/images/pedoman/Ri skesdas\%202010\%20Nasional.pdf

2. Riset Kesehatan Dasar 2013. (2013). Available at:

http://www.depkes.go.id/resources/download/ general/Hasil\%20Riskesdas\%202013.pdf

3. Riset Kesehatan Dasar 2018. (2018). Available at:

http://www.kesmas.kemkes.go.id/assets/uploa d/dir_519d41d8cd98f00/files/Hasil-riskesdas2018_1274.pdf

4. Hariyanto, D., Madiyono, B., Sjarif, D. R. \& Sastroasmoro, S. Hubungan Ketebalan Tunika Intima Media Arteri Carotis dengan Obesitas pada Remaja. Sari Pediatri, 11, 159-66. (2016)

5. Loliana, N. Perbedaan Kebugaran Jasmani, Tekanan Darah, dan Pola Konsumsi antara Remaja Obesitas dengan Non Obesitas di SMA Negeri 5 Surabaya. (Universitas Airlangga, 2015)

6. Asnaini, S. A. Perilaku Konsumsi Fast Food pada Anak dengan Kelebihan Berat Badan di SD Islam Athirah I Kota Makassar Tahun 2016. (Universitas Islam Negeri Alauddin Makassar,

\section{ACKNOWLEDGEMENT}

Penulis berterima kasih kepada Kepala Dinas Pendidikan Provinsi Jawa Timur dan kepada Kepala Sekolah, Wakil Kepala Sekolah, serta Guru SMAN 6 Surabaya yang telah mengizinkan berjalannya penelitian ini.

7. Karnaeni, H. Hubungan Antara Kebiasaan Konsumsi Makanan Cepat Saji Mancanegara (Fast Food), Pola Aktivitas Fisik, dan Faktor Lainnya dengan Status Gizi Pada Remaja SMA Cakra Buana Depok. (Universitas Indonesia, 2005).

8. Ali, R. \& Nuryani, N. Sosial Ekonomi, Konsumsi Fast Food dan Riwayat Obesitas Sebagai Faktor Risiko Obesitas Remaja. Media Gizi Indones. 13, 123-132 (2018).

9. Rafiony, A., Purba, M. B. \& Pramantara, I. D. P. Konsumsi fast food dan soft drink sebagai faktor risiko obesitas pada remaja. J. Gizi Klin. Indones. 11, 170-178 (2015).

10. Arlinda, S. Hubungan Konsumsi Fast Food dengan Obesitas Pada Remaja di SMP Muhammadiyah 10 Yogyakarta. (STIKES Aisyiyah Yogyakarta, 2015).

11. Curtis, A. C. Defining adolescence. J. Adolesc. Fam. Heal. 7, 2-15 (2015).

12. Jang, S. A., Cho, N. \& Yoo, J. Understanding the antecedents of Korean high school students' drinking refusal self-efficacy: parental influence, peer influence, and behavior. Glob. J. Health Sci. 4, 10 (2012).

13. Hamzah, S. R., Ismail, M. \& Nor, Z. M. Does 
attachment to parents and peers influence health literacy among adolescents in Malaysia? Kontakt 20, 348-355 (2018).

14. Nomate, E. S., Nur, M. L. \& Toy, S. M. Hubungan teman sebaya, citra tubuh dan pola konsumsi dengan status gizi remaja putri. Unnes J. Public Heal. 6, 141-147 (2017).

15. Bruening, M. et al. Associations between sugarsweetened beverage consumption and fastfood restaurant frequency among adolescents and their friends. J. Nutr. Educ. Behav. 46, 277285 (2014).

16. Gordon, L. M. The Differential Effects Of Peer Influence And Advertisement On Healthy Food Choices. (Fort Hays State University, 2015).

17. Ramadhani, N. Hubungan Stress Akademik dengan Perilaku Makan, Pola Konsumsi Makan dan Status Gizi Remaja di SMAN 6 Surabaya. (Universitas Airlangga, 2019)

18. Lemeshow, S., Hosmer, D. W., Klar, J., \& Lwanga, S. K. Adequacy of sample size in health studies. (John Wiley \& Sons, 1990).

19. World Health Organization. A Simplified General Method for Cluster-Sample Surveys of Health in Developing Countries. (1991). Available at: https://apps.who.int/iris/bitstream/handle/106 65/41607/0471925179_eng.pdf;jsessionid=DC4 5F6AB353B7398B487FA14ABF9CF40?sequence $=1$

20. World Health Organization. Strengthening the Health Sector Response to Adolescent Health and Development. (2009). Available at: https://www.who.int/maternal_child_adolesce nt/documents/cah_adh_flyer_2010/en/

21. Mukai, T. Mothers, peers and perceived pressure to diet among Japanese adolescent girls. J. Res. Adolesc. (1996).
22. Suswanti, I. Faktor-Faktor yang Berhubungan dengan Pemilihan Makanan Cepat Saji pada Mahasiswa Fakultas Kedokteran dan IImu Kesehatan UIN Syarif Hidayatullah Jakarta Tahun 2012. (UIN Syarif Hidayatullah Jakarta, 2013).

23. Ausubel, D. P. Theory and problems of adolescent development. (Grunne \& Stratton, 2002).

24. Sudiyarto, S., Yuliati, N., Uhertiana, I. \& Pratiwi, L. F. L. Exploring youngest consumers perceptions of traditional foods and fast foods product in Java Island. in AIP Conference Proceedings 2019, 30006 (AIP Publishing, 2018).

25. Hadley, C., Weaver, L. J., Tesema, F. \& Tessema, F. Do People Agree on What Foods are Prestigious? Evidence of a Single, Shared Cultural Model of Food in Urban Ethiopia and Rural Brazil. Ecol. Food Nutr. 58, 93-103 (2019).

26. Triratnawati, A. Makna susu bagi konsumen mahasiswa di kafe susu di Yogyakarta: antara gizi dan gengsi. J. Gizi Klin. Indones. 14, 27-35 (2017).

27. Maxfield, A., Patil, S. \& Cunningham, S. A. Globalization and food prestige among Indian adolescents. Ecol. Food Nutr. 55, 341-364 (2016).

28. Banna, J. C., Buchthal, O. V., Delormier, T., Creed-Kanashiro, H. M. \& Penny, M. E. Influences on eating: a qualitative study of adolescents in a periurban area in Lima, Peru. BMC Public Health 16, 2-11 (2015).

29. Romo, L. F., Mireles-Rios, R. \& Hurtado, A. Cultural, media, and peer influences on body beauty perceptions of Mexican American adolescent girls. J. Adolesc. Res. 31, 474-501 (2016). 